\title{
URBAN FACILITIES IN THE QUALITY OF LIFE RESEARCH: A CASE STUDY OF BANSKÁ BYSTRICA CITY (CENTRAL SLOVAKIA)
}

\author{
Katarína Rišová*, Richard Pouš** \\ * Geografický ústav SAV, Štefánikova 49, 81473 Bratislava, geogriso@savba.sk \\ ** Univerzita Mateja Bela v Banskej Bystrici, Fakulta prírodných vied, Katedra geografie a geológie, \\ Tajovského 40, 97401 Banská Bystrica, richard.pous@umb.sk
}

\begin{abstract}
Urban facilities in the quality of life research: a case study of Banská Bystrica city (Central Slovakia)

The presented paper deals with the quality of urban life (QoUL), looking at urban facilities. The main goal of this study was the QoUL comparison of selected basic settlement units (BSU) in the city of Banská Bystrica (Central Slovakia). For this purpose, the mean spacing method, method of availability of facility per 1,000 inhabitants, as well as multi-criteria statistical analysis techniques were implemented. For micro-level analysis of disparities, the coefficient of variation was used. In all cases, the BSUs with the highest functional variability reached the most favourable results. Al-though most studies using objective indicators usually rely on secondary data sources, this paper provides us with primary data thanks to the field research. In the future, such studies may be used for urban planning, as well as for a housing search based on rational choice.
\end{abstract}

Key words: quality of life, quality of place, facilities, micro-level disparities, urban sustainability, city of Banská Bystrica, Slovakia

\section{INTRODUCTION}

Quality of life (QoL) has long been the well-known geographical subject, of which the theoretical framework has been mentioned in papers by renowned world experts (e.g. Cutter 1985, Diener and Suh 1997, Gyourko et al. 1999, Rogerson 1999, Andrews 2001, Massam 2002, Pacione 2003, Brereton et al. 2008, Marans and Stimson 2011, Stimson and Marans 2011, Ballas 2013 and Marans 2015) as well as in studies of Slovak authors (Ira and Andráško 2007. Andráško 2008a, 2008b, 2009, 2013 and 2016, Ira and Murgaš 2008, Ira et. al. 2009, Angelovič and Ištok 2016 and Rišová 2016).

Despite disputes about the absence of a generally valid QoL definition (e.g. Ira and Andráško 2007), there have already been attempts at such enunciation. In the Dictionary of Human Geography, QoL is defined as "a concept linked to that of social well-being, which is based on the argument that human condition should be evaluated on a wider range of indicators than just income." (Johnston 2009, p. 606 - 607) or as "the state of social well-being of individuals or groups, either as they perceive it or as it is identified by observable indicators." (Johnston 2004, p. $662-$ 663). The quality of urban life (QoUL) relates to a wide range of city development factors (Rogerson 1999 and Royuela et al. 2010) as well as housing choices (Diener and Suh 1997, Faggian and Royuela 2010 and Ballas 2013).

It is a complex multidisciplinary issue for which no uniform methodology of measurement has been developed yet. QoL may be characterized by its twodimensionality (e.g. Massam 2002, Pacione 2003 and Ira and Andráško 2007). The first is the subjective dimension, often expressed as e.g. a psychological one 
(Massam 2002), well-being (Massam 2002, Ira and Andráško 2007, Murgaš 2016 and Murgaš and Klobučník 2016), life satisfaction (Massam 2002, Ira and Andráško 2007), individual/personal QoL (Massam 2002). With respect to the subjective approach, a researcher focuses on an individual's satisfaction with his (or her) life and the environment in which he (or she) lives. The objective dimension looks at measurable aspects of the studied environment while using objective indicators such as wages, rents, air pollution, proximity to green spaces etc. For the objective dimension various terms have been used, e.g. environmental QoL (Massam 2002), living conditions (Ira 2015, Šoltés and Nováková 2015 and 2016), liveability (Pacione 2003 and van Kamp et al. 2003), sustainability (Massam 2002 and Ira and Andráško 2010) and quality of place (Andrews 2001, Marans 2003, Murgaš 2016 and Murgaš and Klobučník 2016). Andrews (2001) defined quality of place (QoP) as an "aggregate measure of the factors in the external environment that contribute to QoL." There is wide agreement that places where we live affect our well-being (Ballas 2013 and Murgaš and Klobučník 2016). It is therefore useful to evaluate them as the basis for creating "good" or "bad" living conditions.

QoP research can be implemented in the urban, suburban, as well as the ruralscale. In urban-scale case studies, both the objective approach to the QoUL measurement (e.g. Andrews 2001, Mendes and Motizuki 2001, Marlet and van Woerkens 2005, Li and Weng 2007, Andráško 2008c, Clifton et al. 2008, Faggian and Royuella 2010, Paul 2012, Murgaš and Klobučník 2014 and Jindrová 2015), as well as the subjective approach (e.g. Pasaogullari and Doratli 2004, Andráško 2006, Frantál and Vaishar 2008, Fertal'ová and Madziková 2008, Kladivo 2011, Andráško et al. 2013, Curl et al. 2015, Lin 2016, Kapuria 2016, Wang and Wang 2016 and Węziak-Bialowolska 2016) have been implemented.

Since Smith (1973) published the first paper in the field of QoL, the urbanisation rate has risen from $37 \%$ (1975) to 54\% (2014) and it will have reached $66.4 \%$ by 2050 (United Nations 2014a). While the size of cities will surely become larger, it is unclear how QoL in these cities will be affected (Marans 2015). Slovakia had also undergone rapid quantitative urbanization by 1990. According to the World Urbanization Prospects (United Nations 2014b) Slovak urbanization rate had grown from $30 \%$ in 1950 to $56.5 \%$ in 1990 . Central planning and accelerated industrialization in the socialist bloc led to urbanization based on, in some cases illconceived, and generally ideologically biased concepts (Nestorová-Dická and Lovacká 2009 and Šveda 2014) without looking at the quality of housing (Šveda 2014). There was a lack of emphasis on urban facilities and services for citizens (Kubeš 2013).

In the period of socialism, Banská Bystrica experienced the largest population and spatial growth. The decisions of city planners made in the period of socialism have a significant impact on today's morphological, functional and demographic urban structure. The urban territory fragmented by major roads or the missing riverbank at the potentially attractive Hron River are examples of the absence of a conceptual urban solution to the development of Banská Bystrica in the socialist era. For these reasons, the city would certainly deserve a comprehensive research using the both subjective and objective approach to measuring Qol involving the public, experts and city authorities.

According to the QoUL research classification (Andráško 2016), presented research can be classified as an intra-urban QoL study based on objective indicators. 
The objective indicators are relatively easy to quantify, and such results are comparable. The disadvantage of such an approach is the absence of consideration of the citizen's perception (Diener and Suh 1997).

The main goal of the study was to compare selected basic settlement units (BSUs) in the city of Banská Bystrica looking at selected elements of urban facilities. The number, size and location of urban facilities are one of the key aspects influencing QoUL (Massam 2002 and Pacione 2003) or more specifically - QoP. In line with the recommendation of Ira and Murgaš (2008), selected indicators concern the citizen's everyday life. As stated by Godor and Horňák (2010), urban facilities are a well-established domain in the Slovak QoUL research. Such indicators have been used by Ira (2005), Andráško (2008c), Ira and Andráško (2008), Faggian and Royuela (2010), Kladivo and Halás (2012), Paul (2012) and others.

Looking at the previously published QoUL studies by Slovak authors, three research categories have been applied: a subjective approach to intraurban QoL studies (Ira 2004 and 2015, Andráško 2006, Fertal'ová and Madziková 2008 and Andráško et al. 2013), an objective approach to interurban QoL studies (Ira 2005, Andráško 2008c, Ira and Andráško 2008, Andráško 2010, Andráško and Ira 2010, Tej et al. 2012 and Murgaš and Klobučník 2016) and a combination of the objective and subjective approach to QoUL research (Spišiak and Danihelová 1998, Ira and Šuška 2006 and 2008 and Ira and Andráško 2010). All the above-mentioned objective papers were based either exclusively or mainly on secondary data sources. Unlike these papers, our research provides us with primary data analysis thanks to field research, which ensures the data is up-to-date.

\section{STUDY AREA}

The research was concluded in the city of Banská Bystrica with a special emphasis on one of its 13 urban districts - the urban district of Banská Bystrica (UDBB) (Fig. 1). The UDBB boundaries used in this research had been valid until 1 July 2017, when BSU Uhlisko got separated from the area. UDBB is the oldest UD of the city.

The area is unevenly inhabited, mainly due to the rangy relief of the Zvolenská kotlina basin. A complicated relief, slope exposures, as well as mountain barriers have determined the character of the settlement's development. As the number of inhabitants and the BSU area has affected the urban facilities placement, these statistics are presented in Tab. 1.

While before the Second World War Banská Bystrica had been characteristic for its compactness, this tendency began to change in the mid-20th century. The mass influx of new residents was closely related to spatial expansion and the extensive city growth (Baran 2002b). Kmet' (1973) highlighted the fivefold increase of the city's population in the period from the early 20th century to the 1970s.

The beginning of the 1990s met significant changes in the socio-demographic, morphological and functional structure of the city. It was the beginning of the urban intensification period, which became evident mainly in the central locations of UDBB (Hlásny et al. 2002, Baran 2002a and 2002b). Another change was expressed by commercialization and gentrification (Hlásny et al. 2002), especially in the historical core.

UDBB is divided into 16 BSUs (Fig. 1). The uninhabited BSUs were excluded from the research. The positive effect of the exclusion was confirmed by the relia- 
bility statistics using Cronbach's alpha (Cronbach 1951). Finally, the 13 BSU shown in Fig. 1 and Tab. 1 remained in the research.

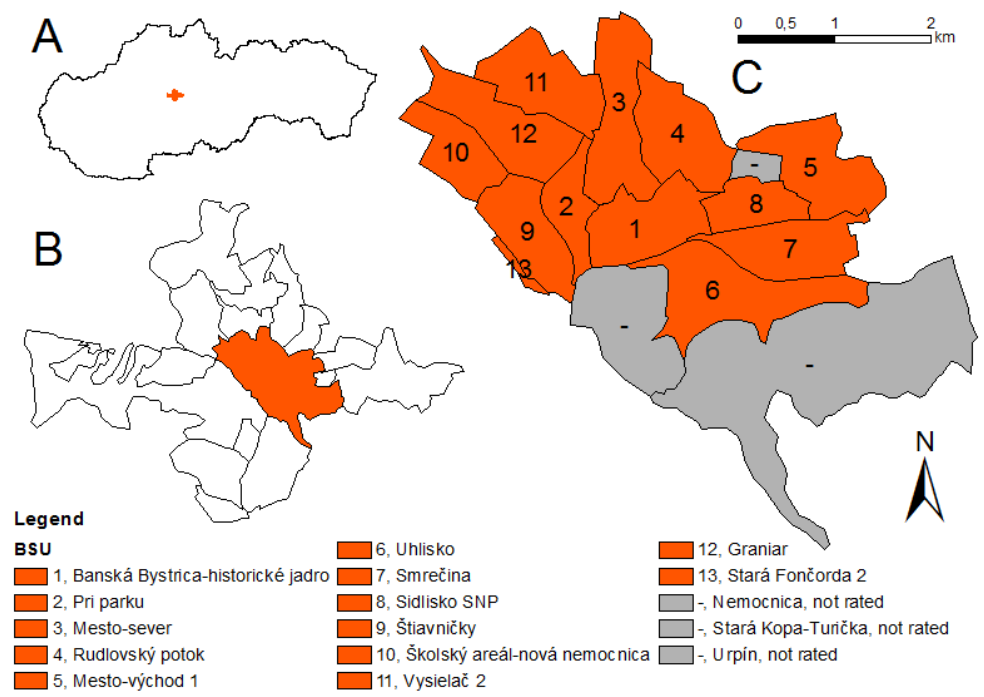

Fig. 1. Study area: part A - location of Banská Bystrica within Slovakia's territory; part $\mathrm{B}$ - location of UDBB within the city of Banská Bystrica and part C - the UDBB territory divided into the BSUs.

Tab. 1. Selected characteristics of studied BSUs

\begin{tabular}{|c|c|c|c|c|}
\hline $\begin{array}{l}\text { BSU } \\
\text { No. }\end{array}$ & $\begin{array}{l}\text { Number } \\
\text { of inhabitants }\end{array}$ & Area $\left(\mathrm{km}^{2}\right)$ & $\begin{array}{l}\text { Number of inhabitants } \\
\text { per } 1 \mathrm{~km}^{2}\end{array}$ & Description \\
\hline 1 & 2,327 & 0.80 & 2,909 & the oldest BSU with the dominating historical core \\
\hline 2 & 269 & 0.44 & 611 & $\begin{array}{l}\text { residential area from the 1930s with greenery, education and } \\
\text { culture elements }\end{array}$ \\
\hline 3 & 2,422 & 1.00 & 2,422 & $\begin{array}{l}\text { functionally heterogeneous BSU. Collective and individual } \\
\text { housing, cemeteries and brownfields included }\end{array}$ \\
\hline 4 & 1,882 & 0.85 & 2,214 & $\begin{array}{l}\text { individual and collective housing, educational, cultural and } \\
\text { governmental buildings }\end{array}$ \\
\hline 5 & 105 & 0.92 & 114 & prevailing production, warehousing and transport functions \\
\hline 6 & 3,358 & 1.20 & 2,798 & prevailing collective and individual housing function \\
\hline 7 & 66 & 0.73 & 90 & $\begin{array}{c}\text { prevailing production, service, warehousing and transport } \\
\text { functions }\end{array}$ \\
\hline 8 & 4,426 & 0.45 & 9,836 & $\begin{array}{l}\text { a housing estate from the 1950s built under the strict compo- } \\
\text { sitional order (Kmet', 1973) }\end{array}$ \\
\hline 9 & 448 & 0.75 & 597 & $\begin{array}{c}\text { includes sports and recreational areas, a transport hub, retail } \\
\text { and collective housing }\end{array}$ \\
\hline 10 & 134 & 0.56 & 239 & $\begin{array}{l}\text { the health care and educational services dominate over the } \\
\text { residential function }\end{array}$ \\
\hline 11 & 141 & 0.88 & 160 & individual housing only with a distinctly suburban character \\
\hline 12 & 525 & 0.82 & 640 & prevailing individual housing and school facilities \\
\hline 13 & 336 & 0.06 & 5,600 & collective housing only \\
\hline Total & 16,439 & 9.46 & 28,230 & \\
\hline
\end{tabular}

Data source: SAŽP (2011), Podmanická (2014). 


\section{DATA AND METHODS}

First of all, the city authorities were asked to provide us the official database of urban facilities. Since this database had not been updated, it was necessary to do a field research. The field research had been running from February to June 2016. Within the research, the following types of urban facilities were mapped: playgrounds (x1), free public sport facilities (x2), grocery stores (x3), bus stops (x4) i.e. all urban public transport stops, including those of trolleybus lines, parks (x5), primary schools (x6), nursery schools (x7), public libraries (x8), pharmacies (x9), automated teller machines ATMs - (x10), bank branches (x11), general practitioners (x12) and post office branches (x13). Although many studies usually attribute different weights to the variables (Massam 2002), this study operates with the research simplifying equal weight system.

The data was analysed on the basis of two complementary methods. The first tool was the Mean spacing method (Mather 1944), in which the results are expressed in the so-called "theoretical distance". The theoretical distance is defined as the distance between the elements in the case of an evenly spaced distribution in a hexagonal pattern composed of equilateral triangles. There is one element of urban facility at each top of the triangle. The pattern is always filled with one urban facility type (e.g. ATMs). The results obtained by the Mean spacing method are predominantly influenced by the area of the BSU and do not consider the BSU population. In the present analysis Mather's method has been used under:

$$
D=1.0746 \sqrt{\frac{A}{N}},
$$

where $D$ is the theoretical distance, $A$ is the area of a BSU and $N$ is the number of facility elements.

The second tool was the method of Availability of urban facility per 1,000 inhabitants. This method does not consider the BSU area. The data was calculated as follows:

$$
a=\frac{N}{I} * 1000,
$$

where $a$ is the availability of urban facility per 1,000 inhabitants, $N$ is the number of facility elements and $I$ is the number of inhabitants.

For both methods Cronbach's alpha test of reliability (Cronbach 1951) was calculated. In this study the value of 0.7 or above is considered acceptable as based on the paper of Peterson (1994), who published an overview of several opinions on the optimal Cronbach's alpha value.

To highlight the disparities among the BSUs, the coefficient of variation (CV) was quantified using the Availability of facility per 1,000 inhabitants' data. The CV was calculated for each facility type separately (e.g. ATMs).

The multivariate statistical file was processed using the scoring method. It enabled us to make the final comparison of the BSUs. For each urban facility type, a BSU with the most conforming value was selected - it was given 100 points. The other BSUs were ranked as follows: 
- for the Availability facility per 1,000 inhabitants

- for the theoretical distance

$$
\begin{aligned}
& b_{i j}=\frac{x_{i j}}{x_{\max , j}} * 100, \\
& b_{i j}=\frac{x_{\min , j}}{x_{i j}} * 100,
\end{aligned}
$$

where $b_{i j}$ is the number of points for $i$-th component for $j$-th indicator, $x_{i j}$ is the value of the $j$-th indicator at the $i$-th component, $x_{\max , j}$ is the highest value of the $j$-th component and $x_{\min , j}$ is the lowest value of the $j$-th component.

The average score achieved for each BSU indicates the QoUL of the particular area. Separately computed types of QoUL were:

- QoUL looking at results of the availability of facilities per 1,000 inhabitants,

- QoUL looking at results of theoretical distance,

- QoUL looking at complex results.

The complex results were calculated by averaging the previous two QoL types. The advantage of the complex results is that they consider the area of BSU, as well as the number of inhabitants.

\section{RESULTS}

\section{Reliability statistics}

In the methodology of the availability of urban facilities per 1,000 inhabitants, the indicator of bus stops $(x 4)$ was omitted from the calculations. Excessively high values for BSU No. 5 (66.67), BSU No. 7 (60.61) and BSU No. 10 (52.24) negatively influenced the reliability of the model. In their presence, Cronbach's alpha reached the value of only 0.60 , which was not acceptable. These are less populated areas with a high degree of urban use by citizens. After the elimination, reliability has reached the value of 0.73 . For the bus stops $(x 4)$ indicator, the key factors are the numbers of bus stops and their spatial distribution. In the Mean Spacing method, Cronbach's alpha reached the value of 0.96. All 13 indicators were therefore considered.

\section{Results looking at the urban facility type}

Playgrounds $(x 1)$ lacked in BSU No. 5 and 7. These are little-populated areas with the predominant functions of industry and transport. This indicator has the lowest degree of variability (CV of 77.1), which indicates the smallest disparities among the BSUs. The values of availability (Tab. 2) ranged from 1.59 (BSU No.4) to 7.46 (BSU No. 10). It was found that better availability of playgrounds was achieved in the BSUs with a low population density. This facility occurred mainly in the collective housing locations, but also in public spaces that are not directly connected to housing (e.g. restaurants, parks and medical buildings). The lowest theoretical distance $(0.19 \mathrm{~km})$ was identified in BSU No. 8 (Tab. 3$)$. The reason is the highest population density (Fig. 2), which has caused a considerable demand for urban facilities. On the contrary, the highest values of the theoretical distance were revealed in less populated BSUs with large area and in the territories with individual housing including gardens.

Free public sport facilities (x2) were missing in BSU No. 5 and 7 (for the same reason as playgrounds), in BSU No. 4 (in the southern and northern part of the 
BSU due to collective housing without a coherent concept, in the middle part of the BSU due to an densely built individual housing neighbourhood) and in BSU No. 11 and 12 (due to the individual housing). The highest availability (Tab. 2) was computed in BSU No. 10 (22.4) with publicly available sport facilities within the campuses. The high degree of variability (CV of 228.3) was caused by the absence in five BSUs, as well as by the highest availability in BSU No.10 and indicates considerable disparities among BSUs. A particularly unfavourable availability was revealed in BSU No.8 (0.23) where, despite the highest population density (Fig. 2), there was only one free public sports area, a running circuit. The lowest theoretical distance $(0.26 \mathrm{~km})$ was recorded in the BSU No.13 (Tab. 3) - because of the extremely small area of the BSU and high population density (Fig. 2).

Grocery stores (x3) were absent in six BSUs (BSU No. 2, 5, 10, 11, 12 and 13). Common features for these BSUs are a low populated area and, in some cases, the peripheral position in the city. For this indicator, the CV of 219.3 was calculated due to the frequent absence in BSUs as well as due to the high availability in BSU No. 7 (15.15) - Tab. 2. The highest availability in BSU No. 7 is caused by the low number of inhabitants (66) and by the location of a hypermarket. It was found that in the areas without sufficient vacant places there were mostly small shops, while in extensively built-up areas there were mostly large stores. The lowest theoretical distance (Tab. 3) was observed in areas with more small-scale grocery stores (BSU No. 1 and 8). In such locations, grocery stores are located on the main routes of movement, in the pedestrian zone, or near public transport stops.

Tab. 2. Availability of facilities per 1,000 inhabitants

\begin{tabular}{cccccccccccccc}
\hline $\begin{array}{c}\text { BSU } \\
\text { No. }\end{array}$ & $\mathrm{x} 1$ & \multicolumn{1}{c}{$\mathrm{x} 2$} & \multicolumn{1}{c}{$\mathrm{x} 3$} & \multicolumn{1}{c}{$\mathrm{x} 4$} & $\mathrm{x} 5$ & $\mathrm{x} 6$ & $\mathrm{x} 7$ & $\mathrm{x} 8$ & $\mathrm{x} 9$ & $\mathrm{x} 10$ & $\mathrm{x} 11$ & $\mathrm{x} 12$ & $\mathrm{x} 13$ \\
\hline 1 & 1.72 & 0.43 & 2.58 & 4.73 & 3.01 & 0.86 & 0.86 & 1.29 & 5.16 & 7.74 & 6.02 & 6.45 & 0.43 \\
2 & 7.43 & 3.72 & 0.00 & 11.15 & 3.72 & 0.00 & 0.00 & 0.00 & 0.00 & 11.15 & 11.15 & 0.00 & 0.00 \\
3 & 3.72 & 1.65 & 0.83 & 4.95 & 0.41 & 0.83 & 0.41 & 0.00 & 0.00 & 0.00 & 0.00 & 0.00 & 0.00 \\
4 & 1.59 & 0.00 & 0.53 & 3.72 & 0.00 & 0.00 & 1.59 & 0.00 & 0.53 & 0.53 & 1.06 & 2.66 & 0.53 \\
5 & 0.00 & 0.00 & 0.00 & 66.67 & 0.00 & 0.00 & 0.00 & 0.00 & 0.00 & 0.00 & 0.00 & 0.00 & 0.00 \\
6 & 2.38 & 0.89 & 0.60 & 2.98 & 0.30 & 0.30 & 0.60 & 0.00 & 0.00 & 0.00 & 0.00 & 0.00 & 0.00 \\
7 & 0.00 & 0.00 & 15.15 & 60.61 & 0.00 & 0.00 & 0.00 & 0.00 & 15.15 & 30.30 & 0.00 & 0.00 & 0.00 \\
8 & 3.16 & 0.23 & 0.68 & 1.58 & 1.13 & 0.23 & 0.68 & 0.23 & 0.45 & 1.13 & 0.68 & 0.23 & 0.00 \\
9 & 6.70 & 2.23 & 4.46 & 8.93 & 2.23 & 0.00 & 2.23 & 0.00 & 4.46 & 22.32 & 15.63 & 4.46 & 0.00 \\
10 & 7.46 & 22.39 & 0.00 & 52.24 & 7.46 & 0.00 & 0.00 & 0.00 & 22.39 & 14.93 & 0.00 & 7.46 & 0.00 \\
11 & 7.09 & 0.00 & 0.00 & 0.00 & 0.00 & 0.00 & 0.00 & 0.00 & 0.00 & 0.00 & 0.00 & 0.00 & 0.00 \\
12 & 1.90 & 0.00 & 0.00 & 1.90 & 0.00 & 0.00 & 0.00 & 0.00 & 0.00 & 0.00 & 0.00 & 0.00 & 0.00 \\
13 & 2.98 & 2.98 & 0.00 & 0.00 & 0.00 & 0.00 & 0.00 & 0.00 & 0.00 & 0.00 & 0.00 & 0.00 & 0.00 \\
\hline
\end{tabular}

$\mathrm{x} 1$ - playgrounds, $\mathrm{x} 2$ - free public sport facilities, $\mathrm{x} 3$ - grocery stores, $\mathrm{x} 4$ - bus stops, $\mathrm{x} 5$ - parks, $\mathrm{x} 6$ - primary schools, $\mathrm{x} 7$ nursery schools, $\mathrm{x} 8$ - public libraries, $\mathrm{x} 9$ - pharmacies, $\mathrm{x} 10$-ATMs, $\mathrm{x} 11$ - bank branches, $\mathrm{x} 12$ - general practitioners, $\mathrm{x} 13$ - post office branches

Bus stops $(x 4)$ were missing in the BSU No. 13 (which is functionally and morphologically connected to the nearby BSU, where bus stops are present), and BSU No. 11 (for its suburban character with individual automobile transportation). The longest theoretical distance $(0.97 \mathrm{~km})$ was computed for BSU No.12 (for the same reasons as in BSU No. 11). The shortest theoretical distance between the bus stops was recorded in the most populated areas (BSU No. 8), as well as in the areas on 
the major intra-urban roads (BSU No. 1) and in the locations near campuses and health care facilities (BSU No. 10) (Tab. 3).

Tab. 3. Theoretical distance between selected facilities identified using the Mean spacing method

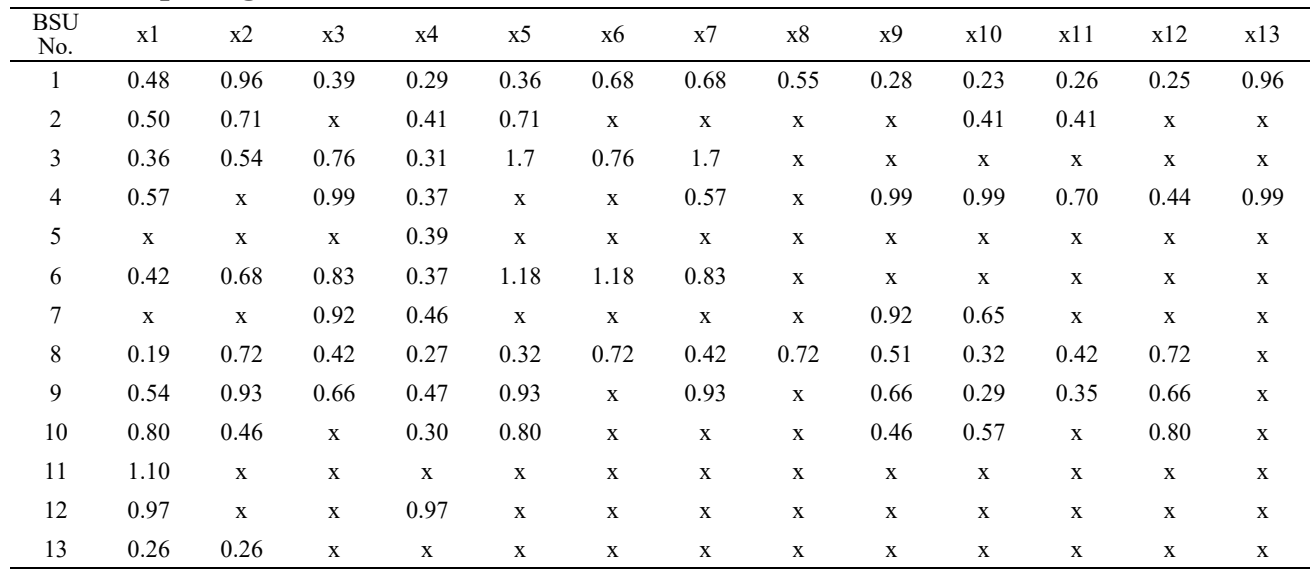

$\mathrm{x} 1$ - playgrounds, $\mathrm{x} 2$ - free public sport facilities, $\mathrm{x} 3$ - grocery stores, $\mathrm{x} 4$ - bus stops, $\mathrm{x} 5$ - parks, x6 - primary schools, $\mathrm{x} 7$ nursery schools, $\mathrm{x} 8$ - public libraries, $\mathrm{x} 9$ - pharmacies, x10-ATMs, x11 - bank branches, x12-general practitioners, x13-post office branches

Parks (x5) were not present mainly in the quantitatively or extensively built-up areas without a coherent urban concept (BSU No. 4 - North and South), in industrial and warehousing zones (BSU No. 5 and 7) and in residential areas with gardens (the centre of BSU No. 4, BSU No.11 and 12). The availability of parks per 1,000 inhabitants (Tab. 2) hasn't caused the depression of the model reliability. Despite that, the data is questionable, as the research hasn't taken into account the area of the parks. It is therefore more beneficial for research to describe the theoretical distance data. The lowest theoretical distance (Tab. 3) had locations built under a coherent compositional order. These BSUs are also enclosed in the urban area, which has caused a poor access to the country (BSU No. 1 and 8). On the contrary, high values of the theoretical distance were calculated in the BSUs with a sufficiency of courtyard greenery (BSU No. 6), areas located on the edge of the city, directly adjacent to the country (also BSU No. 6), extensively urbanized areas (BSU No. 3 - northwest and south, BSU No. 9) and in the residential areas with gardens (BSU No. 3 - east).

Primary schools $(x 6)$ were recorded in four BSUs with the highest number of inhabitants (BSU No. 1, 3, 6 and 8). The CV of 184.9 pointed out to significant disparities among the BSUs. The highest availability of primary schools per 1,000 inhabitants was found in BSU No. $1(0.86)$ and BSU No. $3(0.83)$ - Tab. 2. Here, besides schools within a local reach, there were schools within the city-wide reach (private primary schools and schools focused on the foreign language teaching). The lowest theoretical distance was found in the BSU No. $1(0.68 \mathrm{~km})$.

Nursery schools $(x 7)$ were missing (similar to primary schools) in the areas with fewer inhabitants (BSU No. 2, 5, 7, 10, 11, 12 and 13). BSU No. 9 ensured the best availability of nursery schools $(2.23)$ - Tab. 2, due to the low number of in- 
habitants and the existence of a private nursery school within a city-scale range. The lowest theoretical distance $(0.42 \mathrm{~km})$ was computed for BSU No. 8 (Tab. 3) due to the high population density (Fig. 2).

Public libraries $(x 8)$ have a wide spatial reach. They have been located in only two BSUs and therefore the highest disparities were achieved (CV of 307.0). BSU No.1 is a cultural city centre with a distinctly polyfunctional character. There were public libraries with a full-city and regional reach. BSU No. 8 is characterized by the high demand for services, due to the high population density (Fig. 2).

Pharmacies $(x 9)$ were missing in seven BSUs (BSU No.2, 3, 5, 6, 11, 12, and13) which led to the disparities expressed by the CV of 190.9. The highest availability was calculated in areas with health care facilities (BSU No.10), with retail (BSU No. 7 and 9) and in pedestrian zones (BSU No.1) - Tab. 2. It is evident from the analysis, that the location on the main walking paths has a positive influence on the theoretical distance (BSU No. 1). The longest theoretical distance was recorded in the areas lacking pedestrian options (BSU No. 4 and 7) - Tab. 3.

The existence of ATMs (x10) was connected with the location of the retail, banking and health care services. This indicator absented in six BSUs (BSU No. 3, $5,6,11,12$ and 13) where these services were fewer. From the point of view of availability (Tab. 2) there was a spatial and functional connection to banks, shopping centres (BSU No. 9), hypermarkets (BSU No. 7), hospital (BSU No. 10), and pedestrian zone (BSU No. 1). Within the Mean spacing method, results were positively influenced by the good walking conditions in BSU No.1 $(0.23 \mathrm{~km})-$ Tab. 3 .

Bank branches (x11) were missing in residential areas (BSU No. 3, 6, 11, 12 and 13), industry and transport areas (BSU No. 5 and 7) and in areas typical for health care and educational services (BSU No. 10). Their absence in seven BSUs caused high disparities (CV of 192.7). The highest availability values were reached in areas with shopping centres (BSU No. 9) and with pedestrian zones (BSU No. 1) - Tab. 2. The same patterns were valid for the Mean spacing method, where BSU No. 1 achieved the best value of $0.26 \mathrm{~km}$ (Tab. 3).

General practitioners (x12) were absent in seven BSUs, which is the reason for the high $\mathrm{CV}$ of 185.4. These are areas with the prevailing residential function (BSU No. 3, 6, 11, 12 and 13) and with transiting industrial function (BSU No. 5 and 7). The element was also missing in BSU No. 2. Among the BSUs, the shortest theoretical distance $(0.25 \mathrm{~km})$ and one of the best values for availability $(0.25)$ was revealed in the BSU No. 1 (Tabs. 2 and 3). Location of the general practitioners in this BSU has been connected to the advantages of a central position within the city, the best parking options within the city centre, as well as the proximity of bus stops.

It can be said that post office branches (x 13) have the urban district-wide range. This urban facility type was therefore located in only two BSUs (BSU No. 1 and 4). This fact brought the significant disparities among BSUs expressed by the CV of 245.7. Post office branches were located on the main walking paths of the BSUs with a high number of residents or BSU users.

\section{Comparison of the basic settlement units}

The next step was to compare the monitored BSUs according to the QoUL looking at urban facilities. For this purpose, a scoring method was used. First, the met- 
hod was implemented for the available results. The average score for the BSU determines its ranking in terms of availability of facility per 1,000 inhabitants (Tab. 4).

Tab. 4. The scoring method results using the availability data

\begin{tabular}{crrrrrrrrrrrrrr}
\hline $\begin{array}{c}\text { BSU } \\
\text { No. }\end{array}$ & $\mathrm{x} 1$ & $\mathrm{x} 2$ & $\mathrm{x} 3$ & $\mathrm{x} 5$ & $\mathrm{x} 6$ & $\mathrm{x} 7$ & $\mathrm{x} 8$ & $\mathrm{x} 9$ & $\mathrm{x} 10$ & $\mathrm{x} 11$ & $\mathrm{x} 12$ & $\mathrm{x} 13$ & Score & Ranking \\
\hline 1 & 23 & 2 & 17 & 40 & 100 & 39 & 100 & 23 & 26 & 38 & 86 & 81 & 48 & 1 \\
2 & 100 & 17 & 0 & 50 & 0 & 0 & 0 & 0 & 37 & 71 & 0 & 0 & 23 & 4 \\
3 & 50 & 7 & 5 & 6 & 96 & 19 & 0 & 0 & 0 & 0 & 0 & 0 & 15 & 7 \\
4 & 21 & 0 & 4 & 0 & 0 & 71 & 0 & 2 & 2 & 7 & 36 & 100 & 20 & 6 \\
5 & 0 & 0 & 0 & 0 & 0 & 0 & 0 & 0 & 0 & 0 & 0 & 0 & 0 & 13 \\
6 & 32 & 4 & 4 & 4 & 35 & 27 & 0 & 0 & 0 & 0 & 0 & 0 & 9 & 9 \\
7 & 0 & 0 & 100 & 0 & 0 & 0 & 0 & 68 & 100 & 0 & 0 & 0 & 22 & 5 \\
8 & 42 & 1 & 4 & 15 & 26 & 30 & 18 & 2 & 4 & 4 & 3 & 0 & 13 & 8 \\
9 & 90 & 10 & 29 & 30 & 0 & 100 & 0 & 20 & 74 & 100 & 60 & 0 & 43 & 3 \\
10 & 100 & 100 & 0 & 100 & 0 & 0 & 0 & 100 & 49 & 0 & 100 & 0 & 46 & 2 \\
11 & 95 & 0 & 0 & 0 & 0 & 0 & 0 & 0 & 0 & 0 & 0 & 0 & 8 & 10 \\
12 & 26 & 0 & 0 & 0 & 0 & 0 & 0 & 0 & 0 & 0 & 0 & 0 & 2 & 12 \\
13 & 40 & 13 & 0 & 0 & 0 & 0 & 0 & 0 & 0 & 0 & 0 & 0 & 4 & 11 \\
\hline
\end{tabular}

$\mathrm{x} 1$ - playgrounds, $\mathrm{x} 2$ - free public sport facilities, $\mathrm{x} 3$ - grocery stores, $\mathrm{x} 4$ - bus stops, $\mathrm{x} 5$ - parks, $\mathrm{x} 6$ - primary schools, $\mathrm{x} 7$ nursery schools, $\mathrm{x} 8$ - public libraries, $\mathrm{x} 9$ - pharmacies, $\mathrm{x} 10$ - ATMs, $\mathrm{x} 11$ - bank branches, $\mathrm{x} 12$ - general practitioners, $\mathrm{x} 13$ - post office branches

The best average score was calculated in these BSUs:

BSU No. 1 ranked first place with a score of 48 . Compared to other BSUs, this area excelled in distribution of primary schools and public libraries. Within the UDBB, it has had an important position also due to the location of general practitioners and post office branches. Every urban facility type has had its representation there. The smallest scores were achieved by free public sport facilities and grocery stores. There has been a significant amount of urban facilities, which are used by the inhabitants of the whole city.

BSU No. 10 (a score of 46) is a low populated area in combination with good urban facility infrastructure, which led to a good placement. Urban facilities located in the area are mainly used by employees and visitors of the hospital as well as by students. From the point of view of availability, this BSU excelled in playgrounds, free public sports facilities, parks, pharmacies and general practitioners.

BSU No. 9 (a score of 43) excelled in the availability of nursery schools and bank branches. There was also a favourable number of playgrounds and ATMs. The results were positively influenced by the existence of a shopping centre and the residential area built with an emphasis on young families looking for a higher living standard.

The common pattern of these three BSUs is the whole city-scale and regionalscale range of some facilities located there. BSU No.1 is the cultural centre of the city; BSU No. 10 is the centre of specialized health care facilities and education. In the BSU No. 9 there is a frequently visited shopping centre. These urban facilities have been therefore used not only by the residents of the particular BSUs.

The lowest average score was found in the BSUs with a small functional diversity. These are mainly monofunctional BSUs where residential function (BSU No. 6, 11, 12 and 13), as well as the function of industry (BSU No. 5) prevail. 
GEOGRAFICKÝ ČASOPIS / GEOGRAPHICAL JOURNAL 70 (2018) 2, 99-1 16
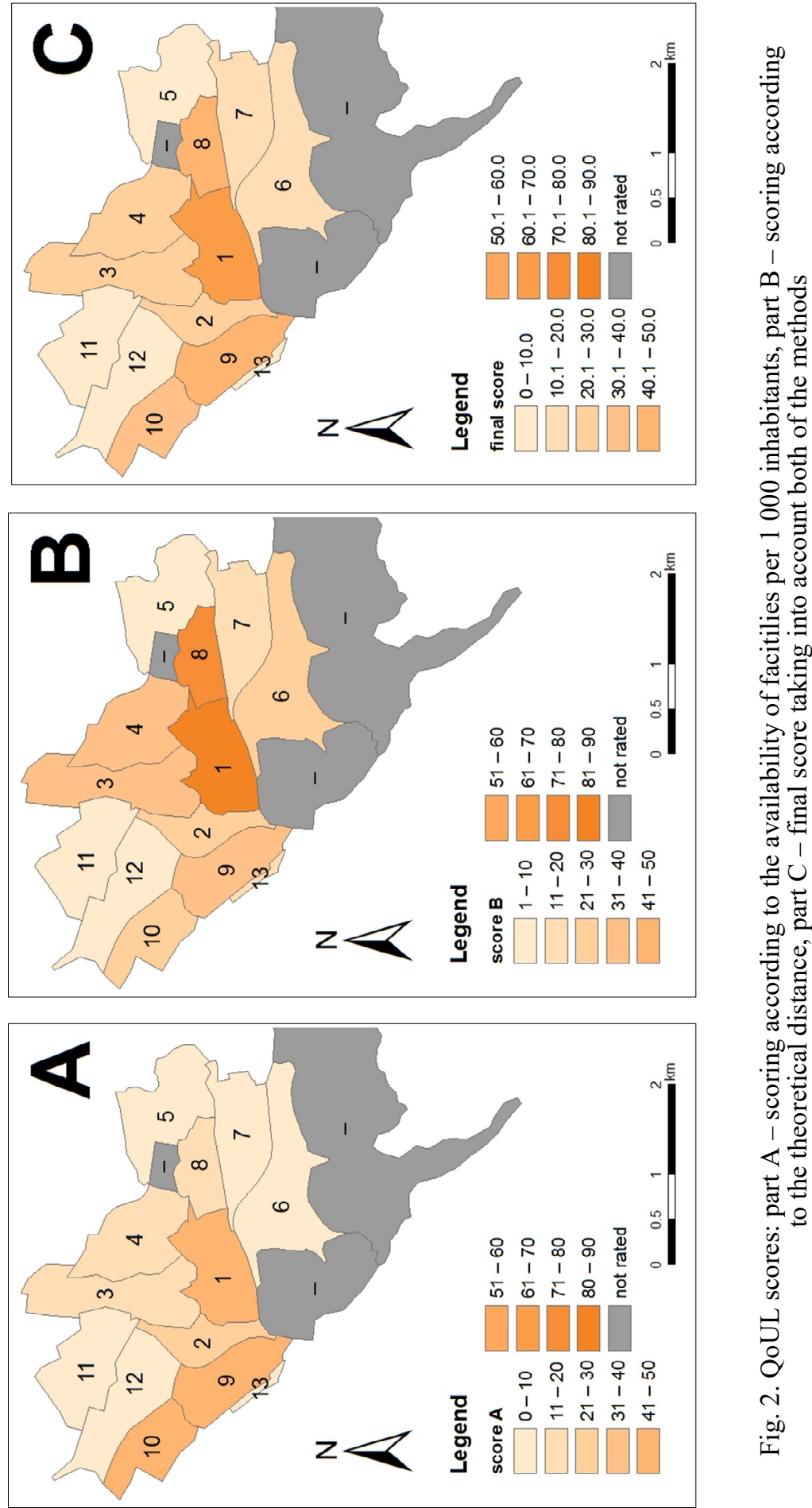
In the second step, the scoring method has been applied to the Mean spacing results (Tab. 5). The BSUs were placed as follows:

BSU No. 1 (a score of 85) excelled in the theoretical distance of grocery stores, primary schools, public libraries, pharmacies, ATMs, bank branches, general practitioners and post office branches. Within the UDBB, this area had also a favourable mean spacing of bus stops and parks. There is a significantly high concentration of urban facilities at a broad pedestrian zone.

Tab. 5. The scoring method results using the theoretical distance data

\begin{tabular}{crrrrrrrrrrrrrrr}
\hline BSU No. & $\mathrm{x} 1$ & $\mathrm{x} 2$ & $\mathrm{x} 3$ & $\mathrm{x} 4$ & $\mathrm{x} 5$ & $\mathrm{x} 6$ & $\mathrm{x} 7$ & $\mathrm{x} 8$ & $\mathrm{x} 9$ & $\mathrm{x} 10$ & $\mathrm{x} 11$ & $\mathrm{x} 12$ & $\mathrm{x} 13$ & Score & Ranking \\
\hline 1 & 40 & 27 & 100 & 94 & 89 & 100 & 61 & 100 & 100 & 100 & 100 & 100 & 100 & 85 & 1 \\
2 & 38 & 37 & 0 & 66 & 45 & 0 & 0 & 0 & 0 & 55 & 62 & 0 & 0 & 23 & 8 \\
3 & 54 & 49 & 52 & 88 & 30 & 89 & 39 & 0 & 0 & 0 & 0 & 0 & 0 & 31 & 5 \\
4 & 34 & 0 & 40 & 73 & 0 & 0 & 73 & 0 & 28 & 23 & 37 & 56 & 97 & 35 & 4 \\
5 & 0 & 0 & 0 & 70 & 0 & 0 & 0 & 0 & 0 & 0 & 0 & 0 & 0 & 5 & 11 \\
6 & 46 & 39 & 47 & 73 & 27 & 58 & 50 & 0 & 0 & 0 & 0 & 0 & 0 & 26 & 6 and 7 \\
7 & 0 & 0 & 43 & 59 & 0 & 0 & 0 & 0 & 30 & 35 & 0 & 0 & 0 & 13 & 9 and 10 \\
8 & 100 & 36 & 94 & 100 & 100 & 94 & 100 & 77 & 54 & 70 & 62 & 34 & 0 & 71 & 2 \\
9 & 36 & 28 & 60 & 58 & 35 & 0 & 45 & 0 & 42 & 77 & 73 & 38 & 0 & 38 & 3 \\
10 & 24 & 57 & 0 & 89 & 40 & 0 & 0 & 0 & 60 & 40 & 0 & 31 & 0 & 26 & 6 and 7 \\
11 & 19 & 0 & 0 & 0 & 0 & 0 & 0 & 0 & 0 & 0 & 0 & 0 & 0 & 1 & 13 \\
12 & 20 & 0 & 0 & 28 & 0 & 0 & 0 & 0 & 0 & 0 & 0 & 0 & 0 & 4 & 12 \\
13 & 73 & 100 & 0 & 0 & 0 & 0 & 0 & 0 & 0 & 0 & 0 & 0 & 0 & 13 & 9 and 10 \\
\hline
\end{tabular}

$\mathrm{x} 1$ - playgrounds, $\mathrm{x} 2$ - free public sport facilities, $\mathrm{x} 3$ - grocery stores, $\mathrm{x} 4$ - bus stops, $\mathrm{x} 5$ - parks, $\mathrm{x} 6$ - primary schools, $\mathrm{x} 7$ nursery schools, $\mathrm{x} 8$ - public libraries, $\mathrm{x} 9$ - pharmacies, $\mathrm{x} 10$ - ATMs, $\mathrm{x} 11$ - bank branches, $\mathrm{x} 12$ - general practitioners, $\mathrm{x} 13$ - post office branches

BSU No. 8 (a score of 71) excelled in the mean spacing of playgrounds, bus stops, parks and nursery schools. It had also strong position in the theoretical distance of grocery stores and primary schools. The good placement could be explained by the relatively small size of the BSU $\left(0,45 \mathrm{~km}^{2}\right)$ with a population density of 9,836 inhabitants per $\mathrm{km}^{2}$ (the highest population density among all BSUs), which creates an increased demand for urban facilities.

The previous two BSUs are followed by the BSU No. 9, BSU No. 4 and BSU No. 3, whose common feature is a functionally fragmented area with a high amount of urbanely unused space. The lowest average score was achieved by the monofunctional residential areas (BSU No. 11 and 12) and industrial zones (BSU No. 5).

The final synthesis of the results revealed the final ranking shown in Tab. 6 . These results are more complex (compared to using only one method), considering number of inhabitants as well as the area of a BSU. The spatial depiction of the final QoUL results are expressed in Fig. 2 part C.

The highest QoUL regarding urban facilities was identified in the BSUs with the highest degree of functional variability. A typical example of this theory is BSU No. 1 followed by BSU No. 8, 9 and 4. Favourable values were achieved also by BSU No. 2 and 3. On the contrary, a low overall score was computed in the 
monofunctional BSUs or in BSUs with an insufficient functional diversity. This situation was recorded in the residential areas (BSU No. 6, 11, 12 and 13), as well as in the areas with a prevailing industrial, warehouse and transport functions (BSU No. 5 and 7).

Tab. 6. The final score of the BSUs

\begin{tabular}{ccc}
\hline Final ranking & BSU No. & Final score \\
\hline 1 & 1 & 66.5 \\
2 & 8 & 42.0 \\
3 & 9 & 40.5 \\
4 & 10 & 36.0 \\
5 & 4 & 27.5 \\
6 and 7 & 2 & 23.0 \\
6 and 7 & 3 & 23.0 \\
8 and 9 & 6 & 17.5 \\
8 and 9 & 7 & 17.5 \\
10 & 13 & 8.5 \\
11 & 11 & 4.5 \\
12 & 12 & 3.0 \\
13 & 5 & 2.5 \\
\hline
\end{tabular}

\section{DISCUSSION AND CONCLUSIONS}

The main goal of the study was to compare the QoUL of selected BSUs in the UDBB territory by looking at urban facilities. On the basis of the field research and quantitative data analysis, the following conclusions can be drawn:

Although the UDBB has a central city location, the facilities are distributed unevenly. After the survey, three major factors positively affecting the QoUL in terms of urban facilities were identified:

- high functional diversity of BSU,

- high concentration of basic (city-forming) urban activities,

- high population density.

The analysis revealed that if none of the above factors is present, the area ends up compared to the other BSUs with a lower score (BSU No. 5, 11 and 12). On the contrary, the BSU, in which all the above factors work, receives a high rating (BSU No. 1).

There is a certain similarity with factors affecting sustainability of a city, such as mixed land use (defined by Haselsteiner et al. (2015, p. 8028) as a "[...] close proximity between housing, workplaces, educational institutions, leisure and supply infrastructure or green spaces"), intensity of land use and urban density (in terms of population density and density of buildings), all of them mentioned by e.g. Thompson (2002), Bertolini (2005), Jabareen (2006), Banister (2008), Silva et al. (2014), Gillis et al. (2015) and Haselsteiner et al. (2015). This supports the theory of Massam (2002), Ira and Andráško (2010) and others that QoUL and sustainability of a city are closely linked together.

The results are valid for the theoretically isolated BSUs. The first reason is that the residents can use the urban facilities of the other BSUs too, which also affects their QoL. The second reason is that BSUs are census units and often do not reflect the morphological and functional urban structure. In future research, the use of oth- 
er spatial units is therefore worth considering. However, such an option may complicate data availability (e.g. population data).

As every individual uses the city in a different way, in the case of more comprehensive research it is advisable to focus on the specific social groups (seniors, families with children, students etc.). In practice, similar research may help with urban planning, but also with better orientation on the real estate market in terms of a rational housing choice.

This paper was supported by the Scientific Agency of the Ministry of Education, science, research and sport of the Slovak Republic and the Slovak Academy of Sciences under the Grant VEGA 1/0049/18.

\section{REFERENCES}

ANDRÁŠKO, I. (2006). Percepcia kvality života v mestských štvrtiach Bratislavy. Geografická revue, 2, 227-240.

ANDRÁŠKO, I. (2008a). Kvalita života jako účast konkurenceschopného regiónu? In Zborník príspěvků z XI. mezinárodního kolokvia o regionálních vědách. Brno (MU), pp. 61-69.

ANDRÁS̆́KO, I. (2008b). Niektoré možnosti využitia multivariačných metód pri štúdiu urbánnej kvality života. Miscellanea geographica, 14, 15-19.

ANDRÁŠKO, I. (2008c). Regionálne typy vnútornej štruktúry Bratislavy z hl'adiska kvality životných podmienok. Geographia Slovaca, 25, 159-173.

ANDRÁSKO, I. (2009). The role and status of geography in the quality of life research. Liberec (Technická univerzita).

ANDRÁŠKO, I. (2010). Kvalita života a kvalita bývania-teoretické aspekty problematiky a príklad hodnotenia kvality bytového fondu. In Klímová V., ed. XIII. mezinárodní kolokvium o regionálních vědách: sborník př́spěvkỉ. Brno (MU), pp. 300-306.

ANDRÁŠKKO, I. (2013). Quality of life: an introduction to the concept. Brno (Masarykova univerzita).

ANDRÁŠKO, I. (2016). Kvalita života v mestách: východiská, prístupy, poznatky. Brno (Masarykova univerzita).

ANDRÁŠKKO, I., IRA, V. (2010). Analýza sociálnej infraštruktúry v okresoch Levice, Žilina, Rimavská Sobota a Bardejov v kontexte vel'kostných kategórií obcí a štandardov ich minimálnej vybavenosti. Geographia Slovaca, 27, 101-133.

ANDRÁŠKO, I., LESOVÁ, P., KUNC, J., TONEV, P. (2013). Perception of quality of life in Brno housing estates. Hungarian Geographical Bulletin, 63, 90-101.

ANDREWS, C. J. (2001). Analyzing quality-of-place. Environment and Planning B: Planning and Design, 28, 201-217.

ANGELOVIČ, M., IŠTOK, R. (2016). How to assess quality of life. Theoretical and methodological research aspects in cross-border regions. Bulletin of Geography. Socioeconomic Series, 32, 19-32.

BALLAS, D. (2013). What makes a 'happy city'? Cities, 32, 39-50.

BANISTER, D. (2008). The sustainable mobility paradigm. Transport policy, 15(2), 73-80.

BARAN, V., ed. (2002a). Historicko-geografické etapy rozvoja mesta a jeho sídelného priestoru. Banská Bystrica v geografickej realite času a priestoru. Acta Facultatis Rerum Naturalium Universitatis Mathiae Belii a mesto Banská Bystrica. Banská Bystrica (FPV UMB).

BARAN, V., ed. (2002b). Formovanie pôdorysnej štruktúry mesta. Banská Bystrica v geografickej realite času a priestoru. Acta Facultatis Rerum Naturalium Universitatis Mathiae Belii a mesto Banská Bystrica. Banská Bystrica (FPV UMB).

BERTOLINI, L. (2005). Sustainable urban mobility, an evolutionary approach. European Spatial Research and Policy, 12, 109. 
BRERETON, F., CLINCH, J. P., FERREIRA, S. (2008). Happiness, geography and the environment. Ecological Economics, 65, 386-396.

CLIFTON, K., EWING, R., KNAAP, G. J., SONG, Y. (2008). Quantitative analysis of urban form: a multidisciplinary review. Journal of Urbanism, 1, 17-45.

CRONBACH, L. J. (1951). Coefficient alpha and the internal structure of tests. Psychometrika, 16, 297-334.

CURL, A., THOMPSON, C. W., ASPINALL, P. (2015). The effectiveness of 'shared space' residential street interventions on self-reported activity levels and quality of life for older people. Landscape and Urban Planning, 139, 117-125.

CUTTER, S. L. (1985). Rating places: a geographer's view on quality of life. Resource Publications in Geography. Washington, D.C. (Association of American Geographers).

DIENER, E., SUH, E. (1997). Measuring quality of life: economic, social, and subjective indicators. Social indicators research, 40, 189-216.

FAGGIAN, A., ROYUELA, V. (2010). Migration flows and quality of life in a metropolitan area: thecase of Barcelona-Spain. Applied Research in Quality of Life, 5, 241-259.

FERTAL'OVÁ, J., MADZIKOVÁ, A. (2008). Percepcia kvality života na príklade mesta Bardejov. Misceillanea Geographica, 14, 105-109.

FRANTÁL, B., VAISHAR, A. (2008). Zvláštnosti kvality života v malých městech. Geografia Slovaca, 25, 175-188.

GILLIS, D., SEMANJSKI, I., LAUWERS, D. (2015). How to monitor sustainable mobility in cities? Literature review in the frame of creating a set of sustainable mobility indicators. Sustainability, 8, 29.

GODOR, M., HORÑÁK, M. (2010). Možnosti využitia indikátorov vo výskume kvality života na Slovensku. Geografické informácie, 14, 42-54.

GYOURKO, J., KAHN, M., TRACY, J. (1999). Quality of life and environmental comparisons. Handbook of regional and urban economics, 3, 1413-1454.

HASELSTEINER, E., SMETSCHKA, B., REMESCH, A., GAUBE, V. (2015). Time-use patterns and sustainable urban form: a case study to explore potential links. Sustainability, 7, 8022-8050.

HLÄSNY, T., KRÁTKA, E., POUŠ, R. (2002). Vývoj a stav využívania zeme v intraviláne mesta Banská Bystrica. In Baran, V., ed. Banská Bystrica v geografickej realite času a priestoru. Acta Facultatis Rerum Naturalium Universitatis Mathiae Belii a mesto Banská Bystrica. Banská Bystrica (FPV UMB).

IRA, V. (2004). City in the mind: behaviorálno-geografické hodnotenie kvality života v meste. Geografické štúdie, 12, 46-52.

IRA, V. (2005). Quality of life and urban space (case studies from city of Bratislava, Slovakia). Europa $X X I, 12,83-96$.

IRA, V. (2015). Petržalka a kvalita života jej obyvatel'ov (subjektívna dimenzia hodnotenia). Zivotné prostredie, 49, 82-86.

IRA, V., ANDRÁŠKO, I. (2007). Kvalita života z pohl'adu humánnej geografie. Geografický časopis, 59, 159-179.

IRA, V., ANDRÁŚKO, I. (2008). Quality of life in the urban environment of Bratislava: two time-spatial perspectives. Geografický časopis, 60, 149-178.

IRA, V., ANDRÁŠKO, I. (2010). Infraštruktúra a vybavenost' obcí: percepcia a hodnotenie vo vybraných regiónoch Slovenska. Sídelná štruktúra Slovenska (diferenciácie v čase a priestore), Geographia Slovaca, 27, 19-40.

IRA, V., ANDRÁŚKO, I., MICHÁLEK, A., PODOLÁK, P. (2009). Quality of life: geographical research in Slovakia. Geographia Slovaca, 26, 101-119.

IRA, V., MURGAŠ, F. (2008). Geografický pohl'ad na kvalitu života a zmeny v spoločnosti na Slovensku. Geographia Slovaca, 25, 7-24.

IRA, V., ŠUŠKA, P. (2006). Percepcia kvality života v mestskom prostredí (na príklade mesta Partizánske). Geografická revue, 2, 309-332.

IRA, V., ŠUŠKA, P. (2008). Premeny mladého industriálneho mesta a ich dopady na kvalitu života na príklade mesta Partizánske. In Změny regionálních struktur České republiky 
a Slovenské republiky. Brno, Olomouc (Ústav geoniky AV ČR, Univerzita Palackého v Olomouci), pp. 67-73.

JABAREEN, Y. R. (2006). Sustainable urban forms: their typologies, models, and concepts. Journal of Planning Education and Research, 26, 38-52.

JINDROVÁ, A. (2015). Application of multivariate statistical methods in the analysis of Czech population life quality with attention to regional differentiation. Acta Universitatis Agriculturae et Silviculturae Mendelianae Brunensis, 63, 1671-1678.

JOHNSTON, R. (2004). Quality of life. In Johnston, R. J., Gregory, D., Pratt, G., Watts, M., eds. The dictionary of human geography. 4th edition. Oxford (Blackwell), pp. 662663.

JOHNSTON, R. (2009). Quality of life. In Gregory, D., Johnston, R., Pratt G., Watts M. J., Whatmore S., eds. The dictionary of human geography. 5th edition. Oxford (Blackwell), pp. 606-607.

KAPURIA, P. (2016). A human well-being perspective to the measurement of quality of life: findings from the city of Delhi. Applied Research in Quality of Life, 11, 125-145.

KLADIVO, P. (2011). Socio-demographic structure of Olomouc from the point of view of the quality of life. Acta Universitatis Palackianae Olomucensis - Geographica, 42, 7990.

KLADIVO, P., HALÁS, M. (2012). Quality of life in an urban environment: a typology of urban units of Olomouc. Quaestiones Geographicae, 31, 49-60.

KMEŤ, L. (1973). Banská Bystrica. Projekt, 15, 32-35.

KUBES, J. (2013). European post-socialist cities and their near hinterland in intra-urban geography literature. Bulletin of Geography. Socio-economic Series, 19(19), 19-43.

LI, G., WENG, Q. (2007). Measuring the quality of life in city of Indianapolis by integration of remote sensing and census data. International Journal of Remote Sensing, 28, 249-267.

LIN, K. (2016). Social quality and happiness - analysis of the survey data from three Chinese Cities. Applied Research in Quality of Life, 11, 23-40.

MARANS, R. W. (2003). Understanding environmental quality through quality of life studies: the 2001 DAS and its use of subjective and objective indicators. Landscape and Urban Planning, 65, 73-83.

MARANS, R. W. (2015). Quality of urban life \& environmental sustainability studies: future linkage opportunities. Habitat International, 45, 47-52.

MARANS, R. W., STIMSON, R. (2011). An overview of quality of urban life. Investigating quality of urban life, 45, 1-29.

MARLET, G. A., Van WOERKENS, C. (2005). Tolerance, aesthetics, amenities or jobs? Dutch city attraction to the creative class. Discussion Paper Series/Tjalling $C$. Koopmans Research Institute, 5(33).

MASSAM, B. H. (2002). Quality of life: public planning and private living. Progress in Planning, 58, 141-227.

MATHER, E. (1944). A linear-distance map of farm population in the United States. Annals of the Association of American Geographers, 34, 173-180.

MENDES, J. F., MOTIZUKI, W. S. (2001). Urban quality of life evaluation scenarios: the case of São Carlos in Brazil. CTBUH review, 1(2), 13-23.

MURGAŠ, F. (2016). Geographical Conceptualization of Quality of Life. Ekológia (Bratislava), 35, 309-319,

MURGAŠ, F., KLOBUČNÍK, M. (2014). Municipalities and regions as good places to live: Index of quality of life in the Czech Republic. Applied Research in Quality of Life, 11, 553-570.

MURGAŠ, F., KLOBUČNÍK, M. (2016). Does the Quality of a Place Affect Well-being? Ekológia (Bratislava), 35, 3224-239.

NESTOROVÁ-DICKÁ, J., LOVACKÁ, S. (2009). Vývojové etapy európskych miest (procesy utvárajúce a formujúce európske mestá). Geographia Cassoviensis, 3, 127-132.

PACIONE, M. (2003). Urban environmental quality and human wellbeing - a social geographical perspective. Landscape and urban planning, 65, 19-30. 
PASAOGULLARI, N., DORATLI, N. (2004). Measuring accessibility and utilization of public spaces in Famagusta. Cities, 21, 225-232.

PAUL, S. (2012). Analysis of micro level disparities in urban facility-utility services: a study on Barasat city, West Bengal, India. Journal of Urban and Regional Analysis, 4, 173-188.

PETERSON, R. A. (1994). A meta-analysis of Cronbach's coefficient alpha. Journal of consumer research, 21, 381-391.

PODMANICKÁ, Z. (2014). Śtatistický lexikón obci Slovenskej republiky. Bratislava (Štatistický úrad Slovenskej republiky).

RIŠOVÁ, K. (2016). Meranie subjektívnej a objektívnej dimenzie kvality života z geografického hl'adiska - prehl'ad prístupov. Folia geographica, 58, 54-69.

ROGERSON, R. J. (1999). Quality of life and city competitiveness. Urban studies, 36, 969985.

ROYUELA, V., MORENO, R., VAYÁ, E. (2010). Influence of quality of life on urban growth: a case study of Barcelona, Spain. Regional Studies, 44, 551-567.

SAŽP (2011). Revízia ZSJ Slovenskej republiky 2011. Bratislava (MŽP SR), [Online]. Available: https://rzsj.enviroportal.sk [accessed 24 October 2017]

SILVA, C., REIS, J. P., PINHO, P. (2014). How urban structure constrains sustainable mobility choices: comparison of Copenhagen and Oporto. Environment and Planning B: Planning and Design, 41, 211-228.

SMITH, D. M. (1973). The geography of social well-being in the United States: an introduction to territorial social indicators. New York (McGraw-Hill).

SPIŠIAK, P., DANIHELOVÁ, D. (1998). Niektoré otázky kvality života v suburbánnom priestore Bratislavy. Acta Facultatis Rerum Naturalium Universitatis Comenianae, Geographica, 41, 155-163.

STIMSON, R., MARANS, R. W. (2011). Objective measurement of quality of life using secondary data analysis. Investigating Quality of Urban Life, 33-53.

ŠOLTÉS, V., NOVÁKOVÁ, B. (2015). Measurement of objective life quality in the context of economically developed countries' quantification. Procedia Economics and Finance, 32, 146-153.

ŠOLTÉS, V., NOVÁKOVÁ, B. (2016). Assessment of material living conditions by the means of integrated indices in the Visegrad group. Polish Journal of Management Studies, 13, 157-167.

ŠVEDA, M. (2014). Bytová výstavba v zázemí vel'kých slovenských miest v kontexte suburbanizácie a regionálnych disparít. Geografia Slovaca, 28, 173-195.

TEJ, J., SIRKOVÁ, M., ALI TAHA, V. (2012). Model and results of the quality of life evaluation in regional cities in Slovakia. Journal of Management and Business: Research and Practice, 4, 31-34.

THOMPSON, C. W. (2002). Urban open space in the 21 st century. Landscape and Urban Planning, 60, 59-72.

UNITED NATIONS (2014a). World urbanization prospects 2014: Highlights. United Nations Publications, 2014.

UNITED NATIONS (2014b). World urbanization prospects 2014: proportion urban, [Online]. Available: https://esa.un.org/unpd/wup/CD-ROM/ [accessed 24 October 2017].

Van KAMP, I., LEIDELMEIJER, K., MARSMAN, G., De HOLLANDER, A. (2003). Urban environmental quality and human well-being: Towards a conceptual framework and demarcation of concepts; a literature study. Landscape and urban planning, 65, 5-18.

WANG, F., WANG, D. (2016). Geography of urban life satisfaction: an empirical study of Beijing. Travel Behaviour and Society, 5, 14-22.

WĘZIAK-BIAŁOWOLSKA, D. (2016). Quality of life in cities - empirical evidence in comparative European perspective. Cities, 58, 87-96. 
Katarína $R$ iš o vá, Richard P o u ̌́

\section{MESTSKÁ VYBAVENOSŤ VO VÝSKUME KVALITY ŽIVOTA: PRÍPADOVÁ ŠTÚDIA MESTA BANSKÁ BYSTRICA (STREDNÉ SLOVENSKO)}

Banská Bystrica zažila $\mathrm{v}$ druhej polovici 20. storočia najväčší priestorový aj populačný rast. Urbanistické rozhodnutia z obdobia socializmu sa dnes vysokou mierou podiel'ajú na jej morfologickej, funkčnej, ale aj demografickej štruktúre, čo sekundárne ovplyvňuje kvalitu mestského života. Územie mesta fragmentované hlavnými dopravnými tahmi či chýbajúce nábrežie pri potenciálne atraktívnej rieke Hron sú príkladmi absencie koncepčného urbanistického riešenia socialistickej výstavby.

Hlavným ciel'om predkladanej práce bolo porovnat' vybrané základné sídelné jednotky (d’alej len ZSJ) v meste Banská Bystrica na základe vybraných kvantitatívnych ukazovatel'ov kvality života v meste, reprezentovanými prvkami vybavenosti. Práca vychádza z predpokladu, že vybavenost' je jedným z kl'účových aspektov ovplyvňujúcich urbánnu kvalitu života, resp. kvalitu miesta (QoP).

Prieskum sa uskutočnil na území mesta Banská Bystrica, a to konkrétne v jeho rovnomennej mestskej časti Banská Bystrica a opiera sa o mapovanie vybraných prvkov vybavenosti, ktoré prebiehalo od februára do júna roku 2016. Mapované boli tieto prvky vybavenosti: detské ihriská (x1), bezplatné verejné športoviská (x2), predajne potravín (x3), zastávky MHD (x4), parky (x5), základné školy (x6), materské školy (x7), verejné knižnice (x8), lekárne (x9), bankomaty (x10), pobočky bánk (x11), ambulancie všeobecných lekárov (x12) a pobočky pôšt (x13).

Po terénnom prieskume nasledovala kvantitatívna analýza založená na dvoch navzájom sa dopín̆ajúcich metódach. Prvou bola metóda mean spacing (Mather 1944), v rámci ktorej sú výsledky vyjadrené tzv. teoretickou vzdialenost'ou medzi prvkami vybavenosti. Druhou v poradí bola metóda dostupnosti prvkov vybavenosti na 1000 obyvatel'ov. Spol'ahlivost' oboch metodík sme otestovali výpočtom Cronbachovej alfy (Cronbach 1951). Vo výpočtoch zohl'adňujeme počet prvkov vybavenosti, počet obyvatel'ov ZSJ, ako aj rozlohu ZSJ s ciel'om uchopit' problém čo najkomplexnejšie. Práca obsahuje vysvetlenia absencie, resp. prítomnosti prvkov vybavenosti $\mathrm{v}$ jednotlivých štvrtiach mesta a smeruje k objasneniu dôvodov ich aktuálnej priestorovej distribúcie. Pre dostupnost' prvkov na 1000 obyvatel'ov sme vypočítali koeficient variácie. Ten poukazuje na disparity medzi jednotlivými ZSJ. Na spracovanie vzniknutého viacrozmerného štatistického súboru a následné porovnanie sledovaných ZSJ sme využili bodovaciu metódu.

V závere môžeme konštatovat', že najvyššia kvalita života z hl'adiska vybavenosti je v tých ZSJ, ktoré vykazujú najvyššiu funkčnú variabilitu. Naopak, monofunkčné ZJS, prípadne ZSJ s malým počtom funkcií vykazujú nízku kvalitu života z hl'adiska vybavenosti. V prieskume sme identifikovali tri hlavné faktory pozitívne ovplyvňujúce kvalita života z hl'adiska vybavenosti: funkčná rôznorodost' ZSJ, vysoká koncentrácia mestotvorných funkcií a vysoká hustota zal'udnenia.

Ukázalo sa, že ak v danej ZSJ nepôsobí ani jeden z uvedených faktorov, toto územie je v porovnaní s inými ZSJ ohodnotené nižším počtom bodov. Ked’že obyvatelia môžu využívat' aj vybavenost' susedných priestorových jednotiek, výsledky sú platné pre teoreticky izolované ZSJ. V prípade rozsiahlejších výskumov tohto typu odporúčame zamerat' sa na špecifické skupiny obyvatel'ov (seniori, rodiny s det'mi, študenti a pod.). V praxi môžu podobné výskumy pomôct' pri územnom plánovaní, ale aj pri orientácii na realitnom trhu v zmysle racionálneho výberu vhodnej lokality na bývanie. 